\title{
Economics of the Sapogenin-Bearing Yam as a Crop Plant in Puerto Rico ${ }^{1}$
}

\author{
F. W. Martin, E. Cabanillas, and M. H. Gaskins ${ }^{2}$
}

INTRODUCTION

Sapogenins extracted from tubers of wild Dioscorra species from Mexico and Central America are the chief source of matcrials for preparing steroid drugs. Such drugs are widely used in treatment of many diseases, and for control of ovulation in humans and animals. Depletion of natural supplies and increasing elinical use of steroid compounds have promoted interest in cultivation of sapogenin-producing Dioscorea species. Field trials have shown that these may be cultivated, and their yields in response to certain cultural practices have been investigated $(1,2, g),{ }^{3}$

This paper discusses and compares cultural practices which have been studied at the Federal Experiment Station at Mayagüez, and provides cost comparisons and estimates of total production costs for growing steroidyielding Dioscorea.

\section{SOURCES OF INFORMATION}

Various accessions of Dioscorea composila Hemsl. and D. floribunda Mart. \& Gal. were used in the experiments which provided the information for this report. The lines used had been selected for superior growth rate and yicld from a larger number of original introductions, but had not been improved by breeding procedures. Many of the basic cultural data were taken from results obtained at this Station. No attempt is made in this paper to substantiate unpublished results, but some of the supporting data will be included in later publications.

Reports of the Department of Agrieultural Statisties of the Conmouwealth of Puerto Rico were consulted for information on crop yields and values, agrieultural wage rates, and lancl-lease costs. Individuals and corporntions engaged in various types of farming were also solicited for infornalion. Costs of various cultural treatments were calculated nffer time and motion studies. All time measurements were replicated at least 3 times. Wage rates of 60 cents per hour for hand labor and 80 cents per hour for machine operators were used in computations. The sost of tractors

I In cooperation with New Crops Research Branch, Crops Resenrch Division, Agricultural Research Service, U.S. Department of Agriculture, Beltsville, Md.

" Plant Geneticist, Agricultural Research Technician, and Officer in Charge, rispentively, Federal Experiment Station, Crops Research Division, Agriculturn! Research Service, U.S. Department of Agriculture, Mayagüez, P.R.

* Itulic numbers in parentheses refer to Literuture Cited, p. 64. 
and other muctinery was considered to be the present rental value of such equipment in l'uerto Rico.

\section{CULTURAL METHODS}

The sapogenin-betring yauns grow well on a variety of soils, but best yields have been obtained on well-drained, fertile loans. Some tests have indicated that higher perentage yields may be obtained in sandy soils or soils low in fortility, but tuber growth has been retarded. Mlore studies of the relation of soil type to yield ate necessury.

Plants may be started from seed in well-drained, weed-free beds proteeted from clinalic extremes. Seeds germimte in about 3 weeks, and seedlings require 5 or 6 months of growth in the nursery before field transplanting. Plants may also be propagated from pieces of the tuber and from single-leaf stem cuttings. When tubers are used for propagntion they are treated with ethylene chlorohydrin to break dormansy, and are then plinted directly in the field. Cuttings must be rooted under mist spray and well established as plants before field transplanting.

Plantings may be made by hand or by a mecharical planter. In the latter case the tubers must be essentially free of soil, and vines nust be cul back to two or three nodes for easy handling. Spacing may vary considerably, but maximum yiolds were obtained at this Station with the closest spacing lested $(1 \times 4$ feet). A system of drainage must be provided. At the Federal Experiment Station this has been accomplished by growing plants on raised beds or ridges.

Dioscorea plants grow slowly for the first few months after their establishment in the field, and require careful protection l'rom weed competition. First-year cultivation costs are high bestuse of the necessity of frecuent hand-weeding operations. Herbicidal control of weeds appears feasible, but cannot be recommended until additional studies have been completed. Weed managenemt is less diffeult in the second and later years of growth, after plants reach sufficient size to iuhibit weeds by shading and conpetition for soil moisture. The more vigorous speeics, $D$. composila, is less vuluer:tble than $D$. floribunda to weed competition.

Dioscorea vines must be supported for efficient growth. Varions nonliving support systems, such as staking and pole-and-wire combinations, have been used satisfactorily. In all experiments in which they have been used, living supportis such as piñon (Jatropha curcas I.), bucare (E'rythrina berteroana Urban), indigo (Indigofera sufruticosa Mill.), and papaya (Carica papaya L.) have severely reduced growth and sapogenin yield.

Probably 3 years of field growth will be required before Dioscorea can be harvested profitably. Even 4 years in the field may prove more profitable with $D$. composita. It will be necessary to remove stakes and vines before 
havesting, and these operalions will probably have to be performed by hand. Menhanical havesting methods have not yet been studied thoroughly, but tests lane demonstrated that lister bot ton plows naty bes used to plow out the cubers. Alter phowing, whers ean be gathered by hand, but marhines to sort fubers from the soil probably wan be developed. Sweetpotato- or polato-harvesting machines may be adiptable for Dioseorea harvesting. Henvier equipment and decper plowing will be necessary with $D$. composita than with $D$. floribunda.

There ans no warketing Cncilities in Puexto Rivo for Dioscorea tubers at this time, but the active mulket demand for steroid precursors suggests that washed, chopped, and sun-dried tuber's could be sold without diffieulty (1) processors in the conimental Huited States. Fiesh tubers ean be sold directly to processors if a plant is located near lihe production area, but if tubers must be shipper long distanees, drying must be anticipated to prevent spoilage in transit and lo reduce shipping costs.

\section{PRODLCION COSTS}

PROPAGATLON

The operations involved in the thee methods of propragation vary considerably. The most ratuid method of establishing new plantations is by planting fuber-pieres directly into tho ficld after fumigation to induce sprouting. 'Chis procedure redues the use of hand labor, eliminates the need for mursery facilities, and lats the advantage of producing vigorous plants rapidly. The disadvantages of the method are that part of the marketable crop nust be sicrified, and that fechnicpes to prevent rot ting of the seed-pieces are not thoroughly reliable. The simplest method of producing large unmbers of plauls is from seed, but 5 or 6 months are recpuired for seedlings to grow sufficiently large for field-planting. The most. complicated method of propagation is from single-leaf stem-cultings. This technique nuy have most applicability in the rapid multiplication of desirable clones for later propagation by tuber-pieses. lor estimated costs of these operations see table 1.

\section{ESTAULINHANG A FIELI)}

Although field-prepuration costs for plowing, disking, and ridging would be similar for all three types of propagules, the difierent malerials will have to be haudled differently and planting costs will not. be the same (table 2). 'The vines of seedlings eam be cut back to a foot or less and the plants then handled in a mechanicul, tractor-pulled transplanter. Tuber-pieces and potted or bunded plants from leaf-cuttings ean be planted with the aid of simple cultivating equipment arranged to open and close the planting 
furrows. However, the estimates reported herein are based on planting by hand labor.

Pre-emergence herbicide treatments to reduce weed competition during the early growth of the plant have not yet been worked out, but an ex-

TавI, 1.-Fistimated costs per acre (in clollars) of production of Dioseorea plants by 3 methods of propagation

\begin{tabular}{|c|c|c|c|}
\hline \multirow{2}{*}{ Operations } & \multicolumn{3}{|c|}{ Cost for indicaled projagation malerial } \\
\hline & Seeds & Stem & Tubers \\
\hline Gathering & 0.60 & 7.20 & 8.10 \\
\hline Cleaning & .60 & - & 13.00 \\
\hline Cutting and dividiug & - & 24.00 & 26.00 \\
\hline Rental of bed & 9.00 & 43.20 & - \\
\hline Seeding & 4.00 & 12.00 & - \\
\hline 'Transplanting & $一$ & 16.10 & - \\
\hline Maintenanee & 16.20 & 9.00 & 一 \\
\hline Digging for ficlel & 2.40 & 1.80 & \\
\hline Market vilue of tuber & 一 & - & 65.00 \\
\hline 'Total & 32.80 & 113.20 & 112.10 \\
\hline
\end{tabular}

TABLE 2,--Estimaled costs per acre (in dollars) of plonting and. and staking a Dioscorea field

\begin{tabular}{|c|c|c|c|}
\hline \multirow{2}{*}{ Operation } & \multicolumn{3}{|c|}{ Cogt for plant sources indicated } \\
\hline & Seeds & Stems & Tubers \\
\hline Rencul of land & 40.00 & 40.00 & 40 \\
\hline Soil preparation & 15.00 & 15.00 & 15 \\
\hline Trunsportation of plants & 1.20 & 3.50 & 2 \\
\hline Transplanting & 60.00 & 120.00 & 80 \\
\hline Herbieide & 25.00 & 25.00 & 25 \\
\hline Staking & 270.00 & 270.00 & 270 \\
\hline Total & 411.20 & 479.50 & 432 \\
\hline
\end{tabular}

pected cost his been computed from data on other crops. The individual farmer will have to manage his staking or support in accordance with locally available materials, but costs herein were calculated on the busis of buying 8-foot poles grown locally, setting these in the ficld, stringing them across the top with one strand of 8-gage galvanized wire, and tying nylon strings from the wire to each plant. 
CULTIVATION, MANTENANCE, FERTILIZATION, ANI) I'EST CONTROL,

Once established in the field the two specics of Dioscorea, from whatever source of propagation naterial, will require approxinately the same amount of naintenance and care. During the first year when plants are small, weeding will have to be done more frequently than in following years. On the other hind, the staking system will require very little maintenance the furst year, but regular mantentance thereafier. Costs were estinated (table 3) for weeding with an oxen-pulled shallow cultivator; for fertilization on the basis of 1,000 pounds per year of a balanced mixture; for insect control on the bisis of two treatments per year of a systemic: insecticide, and for leal-fungus eoutrol, one treatment por year. Haintenane of stakes will

'T+hes 3-Fimated costs per arre per year (in dollars) of cultivation and mainlenance of a Dioscorea plantalion

\begin{tabular}{|c|c|c|c|}
\hline \multirow{2}{*}{ Operation } & \multicolumn{3}{|c|}{ Cost for - - } \\
\hline & Mirst year & & Lator yeats \\
\hline Weoling in rows & 32.50 & $\because$ & 21.50 \\
\hline Fortilizalion & $3 \pi .50$ & . & 37.50 \\
\hline Insect control & 17.00 & : & 17.00 \\
\hline F'ungus control & 15.00 & & 15.00 \\
\hline Siaking maintenunce & $\cdots$ & & 25.00 \\
\hline Total & 102,00 & & 116.00 \\
\hline
\end{tabular}

depend on type of material used and whether it is treated to prevent termites and rotting.

\section{HARVEST}

Lintil techniques are perfected, harvest operations will be expensive, and accurate estimutes of costs camol be made. The first step in such at opexation will be cleanup of the ficld. Strings and vines can be cut and wires removed and rolled up for future use. Tlie labor involved will depend on the density of the vine growth and age of the plants. The posts can be knocked over by a bulldozer or large tractor and the vines and poles raked or carried away. Plowing of the field will then take very little time, and the exposed tubers can be gathered by hand and carried in boxes to trucks or trailers.

Salisfartory systems of washing and drying will have to be developed, but this should not be a serious obstack. The estimates in table 4 were based upon the assumptions that, after the furrows are opened by machine, the tubers will be picked up by hand, and that fubers then be washed with 
a high-pressure pump, chopped with a beet or siluge chopping machine, and sun-dried on a paved sulface or in drying sher, such as is used for drying coffee. The cost of the equipment is included in the estimale of the cost of the washing, chopping and drying operations. Hauling and marketing costs were not calculated herein.

\section{SUMAIATY OF PLOIUUCION COSTS}

Total cosis will be determined by the species used, the method of propngation, and the age of the tuber at harvest (table 5). Costs may differ from those anticipated, depending on the loenl avalability of supplies, the prevailing wage rates and the availability of special equipment. Most opern-

TADLE 4-Estimated costs per aere (in dollars) of harvesting Dioscorea plantulions of virious ages

\begin{tabular}{|c|c|c|c|c|c|c|}
\hline \multirow{3}{*}{ Operation } & \multicolumn{6}{|c|}{ Costs for species indicated } \\
\hline & \multicolumn{3}{|c|}{ D. foribunda } & \multicolumn{3}{|c|}{ D. composilax } \\
\hline & 2 yr. & 3 yr. & 4 y. & $2 \mathrm{yr}$ & 3 yr. & $4 \mathrm{yr}$ \\
\hline Removal of support & 20 & 22 & 22.00 & 24 & 28 & 28 \\
\hline Removal of vines & 8 & 10 & 11.00 & 10 & 14 & 10 \\
\hline Jigging & 12 & 15 & 17.00 & 15 & 20 & 23 \\
\hline Gin thering and loading & 10 & 25 & it, 50 & 20 & 30 & 42 \\
\hline $\begin{array}{l}\text { Wushing, chopping, and } \\
\text { dryiug }\end{array}$ & 20 & $2+$ & 28.00 & 25 & 30 & 40 \\
\hline 'Talal & 76 & 96 & 112.50 & 94 & 122 & 140 \\
\hline
\end{tabular}

tions should be suitable for a high level of mexhanization, but unless largestale operations are anticijuted, some equipment may not be justified.

\section{YIELDS}

For purposes of estimating gross income, yields have been averaged lor' the various soils and cultural treatments used with Dioscorea at Mayagüez. It is recoguized that these variables may have profound effects on yields, but optimum soil drainage, fertilizer, and resticide treatments have not yet been dete.mined. Yields are also related to age of tuber and to species, both of which have been taken into account in ealculating gross income (table 6). Finally, yields are related to source of propagating material, but data are not extensive enough to darify all of these relations.

Dioscorea tuber is purehased on a dry-woight basis. Curront markel valuc is about $\$ 250$ per ton of air-dried tuber of about 4-percent sapogenis. content. The added quality of luber from a single species would result in a 
higher market price. Consequently $\$ 275$ per ton has been selected as an estimated basir price of dried tuber of 4 -percent of sapogenin contenl. Prices of tubers of higher and lower sapogenith concentrations have been calculated as appropriate projortions of this figure (table 7).

PROFLT:

Estimated profits have been calculated based on yields actually obtuined at Mayagüez, and costs as estimuted herein. Certain trends are evident in

TABLE 5.-Summary of Dioscorea tuber production costs per acre (in dollars)

\begin{tabular}{|c|c|c|c|c|c|c|c|}
\hline \multirow{2}{*}{ Syecies } & \multirow{2}{*}{$\begin{array}{c}\text { Age at harvest } \\
\text { (years) }\end{array}$} & \multirow{2}{*}{$\begin{array}{l}\text { Source of } \\
\text { piants }\end{array}$} & \multicolumn{5}{|c|}{ Costs for phases of production indicated } \\
\hline & & & $\begin{array}{c}\text { Propaga- } \\
\text { tion }\end{array}$ & Planting & $\begin{array}{l}\text { Mainte- } \\
\text { mauce }\end{array}$ & Harvesl & Total \\
\hline \multirow[t]{9}{*}{ D. floribunda } & 2 & Sieeds & 32.80 & 411.20 & 218 & 76.00 & 738.00 \\
\hline & 2 & Stems & 113.30 & 479.50 & 218 & 76.00 & 886.80 \\
\hline & 2 & Tubers & 112.10 & 432.00 & 218 & 76.00 & 838.10 \\
\hline & 3 & Seeds & 32.80 & 411.20 & 334 & 06.00 & 874.00 \\
\hline & 3 & Stems & 113.30 & 479.50 & 334 & $06.00^{-}$ & $1,022,80$ \\
\hline & 3 & Tubers & 112.10 & 432.00 & 334 & 96.00 & 974.10 \\
\hline & 4 & Seeds & 32.80 & 411.20 & 450 & 112.50 & $1,006.50$ \\
\hline & 4 & Stems & 113.30 & 479.50 & 450 & 112.50 & 1.155 .30 \\
\hline & 4 & 'lubers & 112.10 & 432.00 & 4.50 & 112.50 & $1,106.60$ \\
\hline \multirow[t]{9}{*}{ D. composita } & 2 & Seeds & 32.80 & 411.20 & 218 & 94.00 & 756.00 \\
\hline & 2 & Slems & 113.30 & 479.50 & 218 & 04.00 & 904.80 \\
\hline & 2 & Tubers & 112.10 & 432.00 & 218 & 91.00 & 850.10 \\
\hline & 3 & Seeds & 32.80 & 411.20 & 334 & 122.00 & 900.00 \\
\hline & 3 & Stems & 113.30 & 479.50 & 334 & 122.00 & $1,048.80$ \\
\hline & 3 & Tubers & 112.10 & 432.00 & 334 & 122.00 & $1,000.18$ \\
\hline & 4 & Seeds & 32.80 & 411.20 & 450 & 149.00 & $1,043.00$ \\
\hline & 4 & Stcms & 113.30 & 479.50 & 450 & 149.00 & $1,191.80$ \\
\hline & 4 & Tubers & 112,10 & 432.00 & 450 & 149.00 & $1,143.10$ \\
\hline
\end{tabular}

table 8 . First, the crop cannot be harvested profitably before the third year. Available duta suggest that potential profits would increase after the third year. Second, estimaled profits from planls grown from seed are lower at all ages than profits from plants grown from tubers. Starting plants from lubers appeurs to provide about a ycar's advantage in terms of rale of growth and final yield, even after subtracting part of the yield which would be needed for teplanting. Unfortunately, very fow yield datn from planis propaguted by stem cuttings are available, but it would appear that such plants are more readily established and grow more rapidly than seedlings, but do not grow as rapidly, or yield as well as plan ls from tuber cuttings. Nevertheless, the stem-cutting technique offers advantages in 


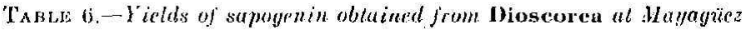

\begin{tabular}{|c|c|c|c|c|c|c|c|}
\hline \multirow{2}{*}{ Species } & \multirow{2}{*}{ Age } & \multirow{2}{*}{ Soil type } & \multirow{2}{*}{$\begin{array}{c}\text { Method of } \\
\text { propingation' }\end{array}$} & \multicolumn{3}{|c|}{ Total yicld per acre } & \multirow{2}{*}{$\begin{array}{l}\text { Menss yielo } \\
\text { srpogenin } \\
\text { per year }\end{array}$} \\
\hline & & & & Dry matter: & Sapo & senin & \\
\hline & Years & & & Pounds & Percent & Ponnds & pounds \\
\hline \multirow[t]{8}{*}{ D. Aloribunda } & 2 & Catalina cluy & $s$ & 2,095 & 4.8 & 101 & 55 \\
\hline & 2 & Nipe cluy & 1 & 4,790 & 6.3 & 310 & 155 \\
\hline & 2 & do. & C & 3,030 & 4.9 & 193 & 96 \\
\hline & 3 & Toa silty loims & $\mathrm{T}$ & 13,600 & 5.3 & 726 & 212 \\
\hline & 3 & Cataline eliny & s & 3,720 & 5.4 & 20.1 & 68 \\
\hline & 4 & do. & $s$ & 6,430 & 5.4 & 346 & 86 \\
\hline & 1 & Nipe clay & $\mathrm{T}$ & 0,250 & 7.9 & 730 & 162 \\
\hline & 5 & Ton silfy loan & $\mathrm{T}$ & 15,520 & 5.2 & 697 & 139 \\
\hline \multirow[t]{10}{*}{ b. composila } & 2 & do. & $\mathrm{T}$ & 6,940 & 1.3 & 93 & 46 \\
\hline & 2 & Cialitos clay & s & 3,240 & 3.3 & 107 & 55 \\
\hline & $2 ! 2$ & Cotrlina clay & $s$ & 6,455 & 3.5 & 226 & 90 \\
\hline & 3 & Tor silly lonm & $\mathrm{T}$ & 21,640 & 4.5 & 960 & 320 \\
\hline & 3 & Cialitos ejay & 8 & 15,730 & 3.7 & 587 & $190^{\circ}$ \\
\hline & 3 & do. & 8 & 7,260 & 3.9 & 284 & 95 \\
\hline & 3 & Nipe clay & $\tau$ & 21,300 & 4.6 & 9884 & 329 \\
\hline & $3 ! 2$ & ('ialitos clity & $s$ & 20,350 & 4.1 & 8.40 & $2: 10$ \\
\hline & $3 ! \frac{1}{2}$ & do, & $\mathrm{s}$ & 13.880 & 1.1 & 644 & 184 \\
\hline & 4 & Catalina elny & 5 & $14: 300$ & 4.7 & 628 & 132 \\
\hline
\end{tabular}

i $S=$ seed; $T=$ tuber; $C=$ culting.

TABLE 7.-Averafe dry weights, percentage of sapogenins, and values of Dioscorea tubers after 2, 3, and $4, y$ cars of field growth

\begin{tabular}{|c|c|c|c|c|c|c|}
\hline Specicy & $\begin{array}{l}\text { Age at } \\
\text { hitivest }\end{array}$ & $\begin{array}{c}\text { Source of } \\
\text { plants }\end{array}$ & Dry weight & Sapogenin & Veluc/ton & Gross vilue \\
\hline & Y'ars & & Pounds: & Pcrcent & Dellars & Dollors \\
\hline \multirow[t]{7}{*}{ D. floribunde } & 2 & Seeds & 2,095 & 4.8 & 330 & 346 \\
\hline & 2 & Stems & 3,930 & 4.9 & $3: 37$ & fiti2 \\
\hline & 2 & Tubers & 3,415 & 6.3 & 433 & 739 \\
\hline & 3 & Soeds & 3,720 & 5.4 & 371 & 690 \\
\hline & 3 & Tubers & 12,225 & 5.3 & 364 & 2.225 \\
\hline & 4 & Seeds & 6,430 & 5.4 & 371 & 1,194 \\
\hline & 4 & Tubers & 7,875 & 7.9 & 543 & 2,138 \\
\hline \multirow[t]{5}{*}{ D. composila } & 2 & Seeds & 3,240 & 3.3 & 226 & 366 \\
\hline & 2 & Tubers & 5,525 & 1.3 & 89 & 240 \\
\hline & 3 & Seeds & 11,405 & 4,2 & 289 & 1,601 \\
\hline & 3 & Tubers & 20,095 & 4.5 & 309 & 3,105 \\
\hline & 4 & Seeds & 14,390 & 4.7 & 323 & $2,32-1$ \\
\hline
\end{tabular}


that high-yielding elones cau be multiplied rapidly without destruetion of tuber materials.

COMPARISONS WITH OTHER choPS

Figures on gross and net income from three principal crops of Puerto Rico were obtained through the courtesy of Sr. Raúl J. 'Tous of the Bureau of Agricultural Statisties for the year 1961-62. These figures are probably realistic except for the sugar figures, which are much lower than profits

TABIE 8.- T'otal and percentage profis erperted from Fioscorea floribunda and D. composita crops harvesied at 2,3 , and 4 years of age

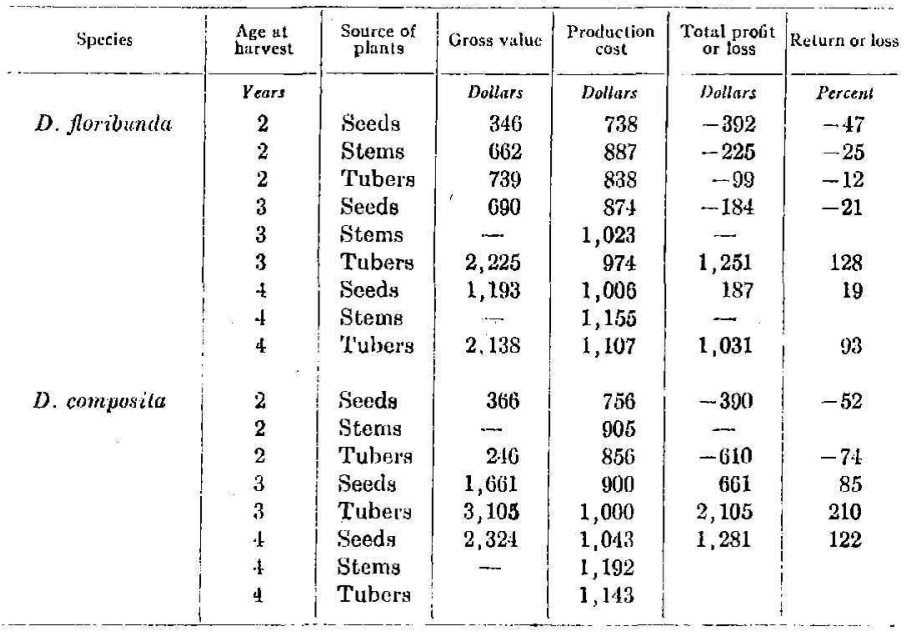

have been during the last wo seasons. Novertheless, these figures ean be compared with some accuracy with those from Dioscorea (table 9). Estimated profits from Dioscorea ufter 3 or 4 years were quite high in comparison to profits from local crops. In most cisses, error's in estimated costs of even $\$ 100$ per acre per year would still allow comfortable profit margins.

\section{DISCUSSION}

The constant increase in demand for steroidal drugs and the fact that Diosconca tuber is the least expensive source of the raw materials used in the synthesis of these drug 3 have suggested the possibility of growing Dioscorea on a commercial basis. Unfortunately, there is no market for the 
tubers in Puerto Rico, and until one develops, the wild yams cannot be recommended as a crop. Shipping costs to a distant market were not calculated herein, but could atd considerably to total costs. Nevertheless, studies of the type reported here may encournge the eventual development of the industry.

Although based on small-seale field plots, and thus subject to error when extrapolated, these ohservalions and calculations suggest that Dioscorea may well compete with the three chief "rops of the Island in terms of estimated net income per acre and interest on investment. Nevertheless, there are several reasons why the rapid development of the industry should not. be anticipated.

TAB1.E 9.-A comparison of mean estimaled income per year per acre from 2 Disseorea species and 3 principal crops of Pnerto Rico

\begin{tabular}{l|c|c|c|c}
\multicolumn{1}{c|}{ Crop } & Gross income & Operating costs & \multicolumn{2}{|c}{ Profit } \\
\cline { 2 - 5 } & Dollars & Dollars & Dollars & Persent \\
Tobaceo & 517 & 374 & 143 & 38 \\
Sugar & 346 & 323 & 23 & 7 \\
Colfee & 121 & 101 & 20 & 20 \\
Dioscorea, 3-year brsis: & & & & \\
D. floribunda tubers & 741 & 325 & 416 & 128 \\
D. composita seedlings & 554 & 300 & 224 & 75 \\
D. composita tubers & 1,035 & 333 & 702 & 211 \\
Dioscorea, 4-year basis: & & & & \\
D. floribunda seedlings & 298 & 252 & 46 & 18 \\
D. floribunda tubers & 534 & 277 & 257 & 93 \\
D. composila seedlings & 581 & 261 & 320 & 122 \\
\hline
\end{tabular}

First, the high costs of establishing the Dioscorea plantation uust be borne for at least 3 years before a crop is ready for harvest.

Second, growing Dioscorea will be a fairly romplex task necessitating careful plaming of unusual famiug and markeling procedures. A certuin amount of inprovisation will be necessary and special equipment nay have to be built or imported.

Third, in the absence of extensive, successful production of medicinal Dioscorea in the past, high risks will be involved. It is possible that unfavorable gro./th may occur in :ome soils or under some climatic conditions. labor costs might be higher than estimated. It is possible that disease problems might beconc serious obstacles in large plantings. Virus and fungus diseases found in Dioscorea plantings are under investigation at the Federal Station. The importance of these diseases has not yet been determined. A full investigation of the risks involved in Dioscorea production 
camot be obtained entirely from experinental plantings. The evaluation of any new crop must eventually include a commcrcial venture on a scale larger than that fractical in experimental investigations.

In the iuterest of stimulating publiv interest in the sipogenin-bearing yam and testing malerials under contrasting ronditions, this Station, in coojerntion with the Agrieultuml Experinent Stalion of the University of Puerto Riro, has established three acre-sized plantings of 1wo species, $D$. floribunda and $D$. composila. These plantings are located at Isabela, Corozal, and Adjuntas. It is anticipated that seed and rlonal material of the better varieties will be naintained at the Federal Experiment Station, and as conditions wardant, will be made available to local liumers or others who have a serious interest in growing this erop plant.

\section{SUMMARY}

From experiments at the Fiederal Experiment Station, Muyagüez, data on costs in Puerto Rico, and other estimates an analysis of the costs of production and potential profits in the growing of Dioscorea were recorded and calculated. The analysis was divided into costs of producing plants, establishing a plantation, yearly maintenance, and harvest. Valucs and profits were ralculated on the basis of species, yields, ages, and rapogenin contents.

The chief suggestions to be made as a result of the study were: That initial costs would be houvy and almost prohibitive; that the greate st single expense would be the cost of staking; that profits would not be possible within less than 3 ycars of field growth; that profits would increase during the fourth year; that $D$. composita could be grown more profitably than D. foribunda; and that plantations established from tuber-pieces would be more profitable than plantations establisher from seed. Provided no scrious pest or disease destroys the plantings, it is concluded that $D_{i}$ oscorea could compete favorably with certain presently existing crops in Puerto Rico.

\section{IRESUM IEN}

En la Estación Experimenlal Fedcral, en Nayagüez, se hizo un estudio sobre cl costo de producir ñames silvestres de los que se usan como fuente jara la sapogenina. EI estudio incluyó el costo de producir las plantas, sembralas en el campo, y mantemimiento y cosecha de lis unbérculos. T'ambién se disculieron lns métodos de siembra que se aplican, los materiales que se usan y la mano de obra. Se estimaron los costos de producción a base de especies, rendimiento, edad y contenido de sapogenina.

El esludio deslacó lo siguiente:

1. Los costos iniciales resultaron muy altos y casi prohibitivos. 
2. La faena uás costosa fue la de estacar Ins plantas.

3. Sería imposible obtener beneficios de plantaciones de menos de 3 años de sembradas.

4. Los beneficios suelen ammentar a $\operatorname{los} 4$ años.

5. La Disscorea composita puede producir más beneticios que la 7 . floribunda.

6. Las plantaciones sembradas ron pedizos de tubereulos dan mayores beneficios que las sembrudas de semilla.

Cono conclusión final puede decirse que, de no aparecer cuformedades o insectos, el género Diosconea puede competir favorablemente con las otras cosechas comerciales de Puerto Rico.

\section{ITTERATURE CITED}

1. Cruzado, H. J., Delpin, H., and Koark, B. А., Wfreets of varions vine supports and spacing distances on steroid production of Dioseorea composila, $7 \mathrm{rop} . \mathrm{Agr}$. $4 \mathrm{l}$ : $345-9,1964$.

2. Kiennard, W. C., and Morris, M. I'., Infuence of cultural practices ou tuber yields and supogenin content of Dioscorea floribunda, Agron. J. 48: 485-7, 1956.

3. Shrum, J. Ji., Jr., Soderlonlın, I'. K., and ILum, J. RR, Preliminary shodies of Itioscorea grow th in Jiorida, Proc. Fla. State Hort. Soc. 71: 315-7, 1058.

\section{SUPPLGMENTARY BIBLIOGRAPIIY}

1. Abrol, 13. K., Chopra, I. C., and Kapoor, L. D., Lixploitation of Jinsterea deltoited in N. W. Himnlayan region, Plunta Med. 11: 44-52, 1863.

2. Correll, D. S., Sehubert, B. G., Gentry, H. S, and Hawley, W. O., The seureh for plant precursor's of cortisone, Econ. Bol. 9: 305-75, 1055.

3. Martin, F. W., Cabunillas, F., and Ortiz, S., Natural pollination, hand pollination, and erossability of some M[exichn Dioseorra speries, Trop. A $m$. $40: 135-11,1963$.

4. Preston, W. H., Jr., and Haun, X. R., Fitetors involved in the vegetalive propagation of Biosecorca spienliffora Hernsl. from viues, Proc. Amer. Soc. Horl. Sci. so: 117-29, 1962. 